\title{
Pengawasan Dewan Perwakilan Rakyat Daerah Terhadap Implementasi Peraturan Daerah Dan Peraturan Bupati Tentang Minuman Keras di Kabupaten Wajo
}

\author{
Mustari Mustari ${ }^{1}$ \\ ${ }^{1}$ Sekolah Tinggi Ilmu Hukum Lamadukelleng, Sengkang \\ Email Correspondensi: mustari112211@gmail.com
}

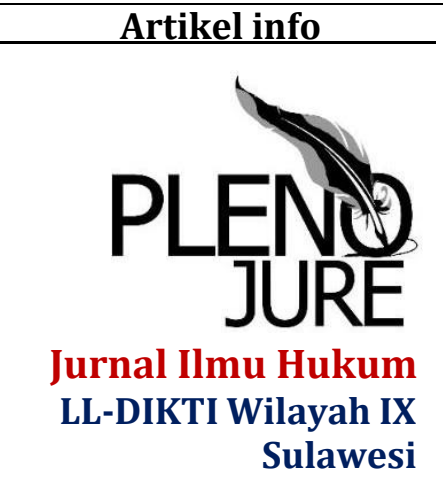

Artikel history:

Received; 15-05-2020

Revised:18-06-2020

Accepted;26-06-2020

\begin{abstract}
Abstrak. Penelitian ini bertujuan mengetahui (1) untuk mengetahui dan menjelaskan bagaimana Pengaturan dan Pelaksanaan fungsi Pengawasan DPRD terhadap Implementasi Peraturan Daerah dan Peraturan Bupati tentang Miras di Kabupaten Wajo, (2) untuk mengetahui dan menjelaskan hambatan-hambatan yang dihadapi DPRD dalam melakukan fungsi Pengawasan terhadap Implementasi Peraturan Daerah dan Peraturan Bupati tentang Miras di Kabupaten Wajo. Penelitian ini dilaksanakan pada Dewan Perwakilan Rakyat Daerah (DPRD) Kabupaten Wajo. Metode yang digunakan dalam penelitian ini adalah penelitian hukum sosioyuridis. Pengambilan sampel dilakukan secara acak dari nara sumber di lokasi penelitian. Data dianalisis dengan menggunakan analisis kualitatif, artinya dengan bertitik tolak pada aturan hukum yang berlaku yang berkembang melalui pembahasan dalam bahan hukum sekunder.

Hasil penelitian menunjukkan bahwa fungsi Pengawasan DPRD terhadap Pemerintah Daerah adalah sebagaimana yang diatur dalam Undang-Undang Nomor 32 Tahun 2004, bahwa Pengawasan merupakan bagian dari pada fungsi DPRD. Pelaksanaan Pengawasan DPRD terhadap Implementasi Peraturan Daerah dan Peraturan Bupati adalah melalui alat kelengkapan DPRD yang tersedia. Hambatan-hambatan dalam melaksanakan Pengawasan DPRD adalah ada yang berasal dari internal dewan dan dari luar dewan.
\end{abstract}

Abstract. This study aims to find out (1) to find out and explain how the Regulation and Implementation of the DPRD Supervisory Function on the Implementation of Regional Regulations and Regents Regulations on Miras in Wajo Regency, (2) to find out and explain the obstacles faced by the $D P R D$ in carrying out the Supervisory function of the Implementation Regional Regulations and Regents Regulations on Miras in Wajo District. This research was conducted at the Regional Representative Council (DPRD) of Wajo Regency. The method used in this research is socio- 


\section{Keywords:}

pengawasan;

peraturan

kabupaten;

minuman keras; juridical law research. Sampling was done randomly from sources at the study site. Data were analyzed using qualitative analysis, meaning that starting with the applicable legal rules that developed through discussion in secondary legal material. The results of the study indicate that the DPRD Supervision function of the Regional Government is as stipulated in Law Number 32 of 2004, that Supervision is part of the DPRD function. Implementation of DPRD Supervision of the Implementation of Regional Regulations and Regents of Regents is through the available DPRD equipment. Obstacles in implementing DPRD Oversight are those that originate from the internal board and from outside the board.

\section{PENDAHULUAN}

Negara demokrasi dengan keberadaan Dewan Perwakilan Rakyat (DPR) dan Dewan Perwakilan Rakyat Daerah (DPRD) atau lembaga legislatif adalah merupakan suatu keharusan, karena lembaga legislatif merupakan perwakilan rakyat dalam membuat Undang-undang ataupun Peraturan Kabupaten/Kota yang akan diberlakukan bagi rakyat. Perubahan Undang-undang tentang keparlemenan mungkin merupakan sebagai "Tradisi Politik Menuju Demokrasi", karena konstitusi negara modern membentuk organ-organ legislatif yang harus diterapkan oleh pengadilan atau organ pemerintah. ${ }^{1}$

Negara demokrasi terdapat pemisahan kekuasaan antara legislatif, eksekutif dan judikatif. Sistem suatu pemerintahan Negara, ketiga jenis kekuasaan itu harus terpisah, baik mengenai fungsi (tugas) maupun mengenai alat perlengkapan (organ) yang melaksanakan:2

1. Kekuasaan Legislatif, dilaksanakan oleh suatu perwakilan rakyat (parlemen);

2. Kekuasaan Eksekutif, dilaksanakan oleh pemerintah (Presiden atau Raja dengan bantuan Menteri-Menteri atau Kabinet);

3. Kekuasaan Yudikatif, dilaksanakan oleh badan peradilan (Mahkamah Agung dan Pengadilan dibawahnya).

Terdapat tiga kekuasaan dalam satu Negara dan ketiga kekuasaan tersebut tidak dipegang oleh satu lembaga saja. Indonesia memiliki semua elemen Trias Politica secara lengkap, praktis apa adanya. Jikalau John Locke memisahkan ketiga lembaga atas dasar pemikiran bahwa "ketiganya merupakan hak paling azasi setiap warga masyarakat dalam hidup bernegara, sistem ketatanegaraan yang berlaku di Indonesia tak lain merupakan

\footnotetext{
${ }^{1}$ Bubandt, N. (2014). Menuju Sebuah Politik Tradisi Yang Baru? Desentralisasi, Konflik, dan Adat di Wilayah Indonesia Timur. Antropologi Indonesia.

2 Djojosoekarto, A. (2004). Dinamika dan kapasitas DPRD dalam tata pemerintahan demokratis. Konrad Adenauer Stiftung.
} 
pengakuan terhadap etika politik yang beriorentasi pada hak-hak warga masyarakatnya." 3

Suatu Negara menjalankan demokrasi bila memenuhi unsur-unsur: ${ }^{4}$

1. Freedom to form and join organization (ada kebebasan untuk membentuk dan menjadi anggota perkumpulan);

2. Freedom of expression (ada kebebasan menyatakan pendapat);

3. The right to vote (ada hak untuk memberikan suara dalam pemungutan suara);

4. Free and fair elections Eligibility to public office (ada kesempatan untuk dipilih atau menduduki berbagai jabatan pemerintahan Negara);

5. The right of political leaders to compete for support and vote (ada hak bagi pemimpin politik berkampanye untuk memperoleh dukungan atau suara);

6. Alternative sources of information (terdapat beberapa sumber informasi);

7. Free and fair elections (adanya pemilihan yang jujur dan bebas);

8. Institutions or making government politics depend on votes and other expresions of preference (lembaga-lembaga yang membuat kebijaksanaan yang bergantung kepada pemilih).

Memasuki era reformasi sampai dengan revisi terhadap Undang-Undang Nomor 22 Tahun 1999 menjadi Undang-Undang Nomor 32 tahun 2004 tentang Pemerintahan Daerah, Undang-Undang ini terus mengalami perubahan hingga ke Undang-Undang Nomor 9 Tahun 2015 tentang Pemerintahan Daerah adalah fase pertama pelaksanaan otonomi daerah, memuat Pasal 1 ayat (2) disebutkan: "Pemerintah Daerah adalah penyelenggaraan urusan Pemerintahan oleh Pemerintah Daerah dan DPRD menurut azas otonomi dan tugas pembantuan dengan prinsif otonomi seluas-luasnya dalam sistem dan prinsip Negara Kesatuan Republik Indonesia sebagaimana dimaksud dalam Undang-Undang Dasar Negara Kesatuan Republik Indonesia Tahun 1945, Sedangkan Dewan Perwakilan Rakyat Daerah disebut DPRD adalah Lembaga Perwakilan Rakyat Daerah sebagai unsur penyelenggara Pemerintahan Daerah". 5

Selanjutnya Wasistino menyatakan dalam penjelasan disebutkan lebih lanjut bahwa: ${ }^{6}$

a. Yang dimaksud dengan fungsi Legislasi adalah Legislasi Daerah yang merupakan fungsi DPRD Kabupaten/Kota untuk membentuk peraturan daerah Kabupaten/ Kota bersama Bupati/Walikota termasuk Pengajuan Rancangan Perda sebagaimana diatur dalam Undang-undang Nomor 10 Tahun 2004 tentang Pembentukan Peraturan Perundang-Undangan, (kini menjadi Undang-Undang Nomor 15 Tahun 2019 tentang Pembentukan Peraturan Perundang-Undangan).

b. Yang dimaksud dengan fungsi Anggaran adalah fungsi DPRD Kabupaten/Kota bersama-sama dengan Pemerintah Daerah untuk

\footnotetext{
3 ibid.

4 Muchsan, M. (1992). Sistem Pengawasan terhadap Perbuatan Aparat Pemerintah dan Peradilan Tata Usaha Negara di Indonesia. Yogyakarta: Liberty.

5 Wasistiono, S., \& Riyani, O. (2003). Etika Hubungan Legislatif-Eksekutif dalam Pelaksanaan Otonomi Daerah. Fokusmedia. Cet. ke-2. Bandung. hal, 19

6 Wasistiono, (2003). ibid, hal 39
} 
menyusun dan menetapkan APBD yang di dalamnya termasuk anggaran untuk pelaksanaan fungsi, tugas, dan wewenang DPRD Kabupaten/Kota.

c. yang dimaksud dengan fungsi Pengawasan adalah fungsi DPRD Kabupaten/Kota untuk melakukan Pengawasan terhadap pelaksanaan Undang-undang, Peraturan Daerah, dan Keputusan Bupati/Walikota serta kebijakan yang ditetapkan oleh Pemerintah Daerah.

Berdasarkan fungsi Legislasi, dimana DPRD Kabupaten/Kota membentuk Peraturan Daerah bersama Bupati/Walikota, olehnya Peraturan Daerah dan Peraturan Kepala Daerah diartikan yakni Peraturan daerah dibuat oleh DPRD bersama-sama Pemerintah Daerah, artinya prakarsa dapat berasal dari DPRD maupun dari Pemerintah Daerah. ${ }^{7}$

Khusus Peraturan Daerah tentang Aggaran pendapatan dan Belanja Daerah (APBD) rancangannya disiapkan oleh Pemerintah Daerah yang telah mencakup keuangan DPRD untuk dibahas bersama. Peraturan Daerah dan ketentuan daerah lainnya yang bersifat mengatur diundangkan dengan menempatkannya dalam Lembaran Daerah. Peraturan daerah tertentu yang mengatur pajak daerah, retribusi daerah, APBD, perubahan APBD, tata ruang, berlakunya setelah melalui tahapan evaluasi oleh Pemerintah. Hal itu ditempuh dengan pertimbangan antara lain untuk melindungi kepentingan umum, penyelaraskan dan penyesuaian dengan peraturan Perundang-undangan yang lebih tinggi dan/atau Peraturan Daerah lainnya, terutama Peraturan Daerah Mengenai Minuman Keras.

Pemerintahan Daerah adalah, penyelenggaraan urusan Pemerintahan oleh Pemerintah Daerah dan DPRD menurut asas otonomi dan tugas pembantuan dengan prinsip otonomi seluas-luasnya dalam sistem dan prinsip Negara Kesatuan Republik Indonesia sebagaimana dimaksud dalam UndangUndang Dasar Negara Kesatuan Repulik Indonesia Tahun 1945, dalam pelaksanaan Pemerintahan Daerah maka dikenal beberapa hal yang berhubungan dengan DPRD, diantaranya terdapat kedudukan dan fungsi, tugas dan wewenang, hak dan kewajiban. ${ }^{8}$ nTujuan dari Kerangka dasar Pengawasan oleh DPRD, walaupun Tata Tertib DPRD telah secara gamblang mengatur mekanisme Pengawasan, hampir semua DPRD menyebutkan bahwa Pengawasan secara Politik yang dilakukan oleh DPRD seringkali menimbulkan hubungan yang kurang harmonis dengan Pemerintah Daerah. ${ }^{9}$

Pengawasan pada hakekatnya melekat pada jabatan pimpinan sebagai pelaksana fungsi manajemen, disamping keharusan melaksanakan fungsi perencanaan dan pelaksanaan. Oleh karena pelaksanaan Pengawasan di dalam administrasi atau manajemen Negara/Pemerintah sangat luas, maka perlu dibedakan macam-macam pengawasan tersebut, yakni: ${ }^{10}$

1. Pengawasan fungsional, yang dilakukan oleh aparatur yang ditugaskan melaksanakan Pengawasan seperti BPKP, Irjenbang, Irjen Departemen dan aparat Pengawasan fungsional lainnya di lembaga Pemerintahan Non Departemen atau Instansi Pemerintah lainnya.

2. Pengawasan Politik, yang dilaksanakan oleh Dewan Perwakilan

\footnotetext{
${ }^{7}$ Mahfud, M. (1999). Pergulatan politik dan hukum di Indonesia. Gama Media. hal, 34

8 Mahfud, ibid. hal, 46

${ }^{9}$ Syuhudi, I. (2018). Pergulatan Kepentingan Politik Dalam Relasi Inter Denominasi Kristen Di Manado. Al-Qalam, 24(2), 235-245.

10 Wasistiono, Loc.Cit. hal, 45
} 
Rakyat (DPR).

3. Pengawasan yang dilakukan oleh BPK sebagai Pengawasan Eksternal Eksekutif.

4. Pengawasan Sosial yang dilakukan oleh mass media, ormas-ormas individu dan anggota masyarakat pada umumnya.

5. Pengawasan melekat, yakni Pengawasan yang dilaksanakan oleh atasan langsung terhadap bawahannya.

Dilihat dari pendapat tersebut di atas yang membedakan lima (5) macam Pengawasan, maka dalam bahasan ini tentu yang dimaksud Pengawasan adalah Pengawasan Politik melalui Dewan Perwakilan Rakyat Daerah (DPRD). Karena yang diawasi adalah Peraturan Daerah dan Peraturan Bupati tentang Minuman Keras, maka yang akan mengawasi adalah Dewan Perwakilan Rakyat Daerah, khususnya Kabupaten Wajo yang menjadi wilayah penelitian dari artikel ini.

Tujuan DPRD sebagai lembaga yang mengawasi Peraturan Daerah dimaksudkan bahwa DPRD melakukan Pengawasan terhadap Peraturan Daerah dan Peraturan Bupati. ${ }^{11}$ Setelah Peraturan Daerah dan Peraturan Bupati itu dibuat bersama antara DPRD dan Bupati, maka DPRD masih perlu mengawasi atas berlakunya Peraturan Daerah dan Peraturan Bupati, tersebut karena Pengawasan adalah merupakan salah satu fungsi DPRD dalam kesinambungan Pemerintahan Daerah, sehingga Peraturan Daerah dan Peraturan Bupati dapat berjalan dengan baik. Olehnya, artikel ini kemudian menetapkan rumusan masalah untuk diuraikan secara konfrehensif terkait pengawasan DPRD Kabupaten Wajo terhadap Peraturan Kabupaten/Kota, serta hambatan dalam pelaksanaan fungsi pengawasannya.

\section{METODE}

Penelitian ini dilaksanakan di Kabupaten Wajo, DPRD sebagai Lembaga Legislatif (Pengawas), Pemerintah Daerah sebagai Lembaga Eksekutif, Polres Pegunungan Wajo Lembaga Yudikatif dan Masyatakat dengan melihat Pelaksanaan Pengawasan DPRD terhadap Implementasi Peraturan Daerah dan Peraturan Bupati tentang Minuman Keras di Kabupaten Wajo, sehingga tipe penelitian ini dilakukan tergolong kajian penelitian hukum sosio-yuridis dengan memperhatikan peraturan perundang-undangan yang mengatur tentang kewenangan DPRD dalam Mengawasi Peraturan Daerah dan Peraturan Bupati serta kebijakan. Penelitian ini juga berupaya memaparkan serta menggambarkan fungsi Pengawasan DPRD terhadap Implementasi Peraturan Daerah dan Peraturan Bupati tentang Minuman Keras di Kabupaten Wajo. Sehingga penelitian ini tidak hanya menitikberatkan pada pengawasan peraturan perundang-undangan saja, melihat sejauhmana realita yang terjadi serta kebiasaan yang hidup dan berkembang dalam masyarakat.

Penelitian ini diarahkan pada pengumpulan jenis dan bahan hukum primer dan sekunder. Bahan hukum primer adalah bahan hukum yang langsung diperoleh dari lapangan berupa hasil pencatatan pengamanan. Bahan Hukum Sekunder adalah Bahan Hukum yang diperoleh dari bahan Hukum dan

\footnotetext{
11 Nurdin, A. (2020). Implementasi Fungsi Legislasi Dewan Perwakilan Rakyat Daerah pada Pembentukan Peraturan Daerah. Al-Ishlah: Jurnal Ilmiah Hukum, 22(1), 53-76. Hal, 55
} 
kepustakaan hukum. ${ }^{12,13}$ Populasi dalam penelitian ini meliputi 35 orang. Yaitu anggota DPRD Kabupaten Wajo sebanyak 10 orang, , 5 orang anggota Reskrim Polres Wajo, 5 orang Akademisi, 5 orang Tokoh Masyarakat, 5 orang Tokoh Agama. Sedangkan sampel dalam penelitian ini adalah total populasi. Upaya mengumpulkan Bahan hukum primer dilakukan dengan cara pengamatan langsung dan sebahagian dengan cara wawancara terhadap pihak yang berkompeten seperti dari DPRD adalah dari Pimpinan DPRD, maupun alat kelengkapan DPRD yang ada, unsur Sekretariat DPRD. Sedangkan dari Pemerintah Daerah bahan hukum primer mewawancarai Sekretariat Daerah dan Kepala Bagian Hukum. Sedangkan dalam mengumpulkan bahan sekunder dilakukan dengan cara studi dokumentasi demikian juga terhadap bahan hukum tertier. Data yang tersedia kemudian dikumpulkan khususnya bahan yang memiliki relevansi dengan tulisan ini. Bahan yang diperoleh arsip Sekretariat DPRD Bagian Hukum Setda Kabupaten Wajo, serta Laporan Tahunan Satuan Reskrim Polres Kabupaten Wajo.

Bahan hukum primer, bahan hukum sekunder yang dikumpulkan oleh peneliti, kemudian diinvetarisasi dan diklasifikasi berdasarkan studi dokumen atau menyesuaikan dengan masalah yang dibahas. Bahan yang diperoleh kemudian dipaparkan, disistematisasi, kemudian dianalisis untuk menginterpretasikan hukum yang berlaku, dalam penelitian ini analisis yang digunakan adalah analisis kualitatif, artinya dengan bertitik tolak pada aturan hukum yang berlaku yang berkembang melalui pembahasan dalam bahan sekunder. Kemudian dengan logika berpikir deduktif, maka semua bahan diseleksi dan diolah serta dianalisis dengan memaparkan apa adanya (deskriptif), maka dengan mengungkapkan permasalahan, juga dengan penelitian ini diharapkan dapat memberikan wacana baru dalam rangka pengawasan yang dilaksankan DPRD terhadap Peraturan Daerah, sehingga dapat diketahui batasan-batasan pengawasan DPRD.

\section{HASIL DAN PEMBAHASAN}

\section{Pengawasan DPRD Kabupaten Wajo terhadap Peraturan Daerah dan Peraturan Bupati}

Pengawasan yang dilakukan DPRD Kabupaten Wajo pada prinsipnya adalah Pengawasan secara Politik, ${ }^{14}$ artikel ini menguraikan fungsi Pengawasan DPRD terhadap Implementasi Peraturan Daerah dan Peraturan Bupati tentang Minuman Keras di Kabupaten Wajo, sejak terbentuknya Kabupaten Wajo melalui Undang-Undang Nomor 4 Tahun 1957 tentang Pembubaran Daerah Bone dan Pembentukan Daerah Bone, Daerah Wajo dan Daerah Soppeng yang diresmikan pada tanggal 16 Januari 1957, sedangkan DPRD Kabupaten Wajo 20 orang dilantik sejak tanggal 25 Oktober 1957.

Dengan tujuan dalam penyelenggaraan pemerintahan Kabupaten Wajo, maka diperlukan Peraturan Daerah serta Peraturan Kepala Daerah maupun peraturan lainnya. Pembuatan Peraturan Daerah dilakukan secara bertahap,

\footnotetext{
${ }^{12}$ Nawi, S. (2014). Penelitian Hukum Normatif Versus Penelitian Hukum Empiris. Umitoha Ukhuwah Grafika, Makassar. hal, 29

${ }^{13}$ Sampara, S. La Ode Husen. (2016). Metode Penelitian Hukum Edisi Revisi. Kretakupa, Makassar. hal, 38

${ }^{14}$ Andi Alaiddin Palaguna, Ketua DPRD Kabupaten Wajo (Wawancara pada tanggal 1 November 2019)
} 
walaupun pembuatan peraturan daerah adalah merupakan prioritas dari DPRD dan pemerintah daerah sekarang, sehingga dalam kurun waktu 5 (lima) tahun yakni tahun 2014 hingga 2019 telah dibuat Peraturan Daerah sebanyak 60, sedangkan Peraturan Bupati sebanyak 30. Jika dilihat dari jumlah Perda yang dihasilkan oleh DPRD bersama Pemerintah Daerah, dimana Perda retribusi adalah yang paling banyak.

DPRD Kabupaten Wajo memiliki 3 (tiga) Komisi yaitu Komisi A membidangi Hukum, Pemerintahan dan Politik; Komisi B membidangi Keuangan dan Pembangunan; Komisi C membidangi Pertanian, Pendidikan, Kesehatan, Sosial, Agama dan Pariwisata; serta terdapat 3 (tiga) Fraksi, meliputi Fraksi Golkar (Golongan Karya), Fraksi PPP (Partai Persatuan Pembangunan) dan Fraksi Gabungan. Perda Kabupaten Wajo yang dibentuk disamping Perda retribusi juga perda pajak daerah, institusi maupun perda lainnya. Sejak terbentuknya Kabupaten Wajo hingga 2018, jumlah perda yang telah dibuat sebanyak 33 Perda terdiri dari: tentang retribusi 5 Perda, tentang pajak 10 Perda, tentang organisasi 10 Perda, Tentang APBD 5 Perda, Tentang Minuman Keras 1 Perda, dan lainnya 2 Perda.

a. Peraturan Daerah Wajo

Diantara 33 Peraturan Daerah Wajo, 8 (delapan) diantaranya telah diubah, sedangkan 5 (lima) Peraturan Daerah telah dinyatakan dicabut yakni penyesuaian dengan peraturan yang lebih tinggi. ${ }^{15}$ Adanya Peraturan Daerah tentang retribusi yang diubah pada dasarnya akibat penyesuaian tarif retribusi yang dianggap tidak sesuai dengan kenaikan harga akibat laju inflasi, maka diadakan penyesuaian, sedangkan peraturan daerah yang dicabut sehubungan dengan dikeluarkannya Peraturan Pemerintah Nomor 41 Tahun 2007 tentang Organisasi Perangkat Daerah. Sehingga tujuan dengan keluarnya PP Nomor 41 Tahun 2007 tersebut, dimana terjadi perombakan terhadap struktur organisasi dan tata kerja perangkat daerah di lingkungan Pemerintahan Daerah Kabupaten Wajo. Maka peraturan daerah yang mengatur tentang struktur organisasi yang lama harus dicabut atau disesuaikan dengan PP Nomor 41 Tahun 2007 tersebut. Jika ada peraturan daerah yang dianggap bertentang dengan kepentingan umum dan/atau peraturan yang lebih tinggi, maka sebagaimana yang diatur dalam Pasal 145 ayat (2) UndangUndang Nomor 9 Tahun 2015, maka perda tersebut dapat dibatalkan oleh Pemerintah. Sebagaimana yang diatur dalam Undang-Undang Nomor 9 Tahun 2015 tersebut, belum ada sanksinya jika terdapat peraturan daerah yang bertentang kepentingan umum dan/atau peraturan yang lebih tinggi.

b. Peraturan Bupati Wajo

Peraturan Daerah dan Peraturan Bupati Wajo tersebut di atas merupakan landasan hukum Pemerintah Wajo dalam menyelenggarakan pemerintahan di samping peraturan perundang-undangan yang lebih tinggi. Maka tujuan pengawasan yang dilaksanakan DPRD sebagaimana yang diuraikan di atas adalah terhadap Perda dan Peraturan Bupati

15 Imran Hameru, Mantan Anggota DPRD Kabupaten Wajo Periode 2015 (Wawancara pada tanggal, 3 November 2019) 
tersebut. 16 Fungsi pengawasan Dewan Perwakilan Rakyat Daerah terhadap pemerintah daerah bersifat pengawasan kebijakan dan bukan pengawasan teknis. Demikian halnya pengawasan yang telah diuraikan di atas dimana DPRD dalam melaksanakan pengawasan terhadap implementasi Peraturan Daerah maupun Peraturan Bupati, bersifat pengawasan kebijakan. Artinya pengawasan terhadap Kebijakan, yang muatannya agar pelaksanaan pengawasan itu sesuai dengan perundangundangan maupun tata tertib yang ada. ${ }^{17}$

Pengawasan terhadap program dimaksudkan pengawasan DPRD terhadap program pembangunan, yakni apakah pembangunan yang dilaksanakan sudah sesuai dengan mata anggaran yang termuat dalam APBD. ${ }^{18}$ Sedangkan tujuan pengawasan terhadap proyek, memang seringkali pengawasan DPRD masuk kewilayah teknis. Misalnya, DPRD melakukan pengawasan terhadap pembangunan gedung atau fasilitas infrastruktur lain, maka pengawasan seperti ini telah menimbulkan hubungan yang kurang harmonis dengan pemerintah daerah, sehingga pengawasan yang dilakukan DPRD terhadap proyek adalah terhadap proyek yang bermasalah atau bertentangan dengan kebijakan daerah maupun nasional.

Hasil penelitian yang dilakukan akibat lemahnya fungsi pengawasan DPRD sehingga ada beberapa hal yang belum dilaksanakan secara maksimal oleh DPRD Kabupaten Wajo terhadap implementasi Peraturan Daerah dan Peraturan Bupati yang berkaitan dengan Minuman Keras antar lain yaitu adanya tarik ulur kepentingan antara pemerintah dan anggota DPRD, sehingga hak DPRD yang semestinya dapat digunakan seperti hak interpelasi, hak angket, hak menyatakan pendapat tidak dapat dimaksimalkan. Terkait rancangan penyusunan peraturan daerah Kabupaten Wajo sampai dengan diundangkan dalam lembaran daerah DPRD Kabupaten Wajo selalu menyampaikan hasil rancangan maupun hasil Perda kepada Kepolisian Resor Wajo sebagai mitra kerja, hal ini dilakukan guna mendukung dan mengefektifkan suatu Perda yang telah ditetapkan, termasuk Perda Minuman Keras. Meskipun demikian dalam pelaksanaan penegakan suatu Perda khususnya Perda Minuman Keras tidak serta merta dilakukan penindakan, dikarenakan didalam proses penegakan Perda bukan ranah Kepolisian melainkan ranah Penyidik Pegawai Negeri Sipil, namun di Kabupaten Wajo belum dibentuknya Penyidik Pegawai Negeri Sipil sebagai penegak peraturan di lingkungan pemerintahan. ${ }^{19}$

\footnotetext{
16 Yunus Panaungi, Anggota DPRD Kabupaten Wajo (Wawancara pada tanggal, 2 November 2019)

17 Lihat penjelasan, Peraturan Pemerintah Nomor 12 tahun 2017 tentang Pembinaan dan Pengawasan Penyelenggaraan Pemerintahan Daerah.

18 Mahfud, M. (1999). Loc.Cit, hal, 34

${ }^{19}$ Yunus Panaungi, Anggota DPRD Kabupaten Wajo (Wawancara pada tanggal, 2 November 2019)
} 


\section{c. Pengaturan dan Kandungan Alkohol}

Kitab Undang- undang Hukum Pidana (KUHP) mengatur masalah mabuk dalam 3 (tiga) buah Pasalnya. Pasal-pasal tersebut adalah Pasal 300, pasal 492 dan pasal 536 KUHP.

Isi pokok dan pasal-pasal tersebut adalah:

a. Menyerahkan minuman yang memabukkan pada orang yang dalam keadaan mabuk (Pasal 300 ayat (1) ke 1 KUHP).

b. Membuat mabuk seorang anak di bawah usia 16 tahun (Pasal 300 ayat (1) ke 2 KUHP)

c. Dalam keadaan mabuk mengganggu ketertiban di tempat umum (Pasal 492 ayat (1) KUHP)

d. Dalam keadaan mabuk berada di jalanan umum (Pasal 536 ayat (1) KUHP)

Seseorang yang betul-betul mabuk, tidak bisa berbuat apa-apa. Terhadap orang mabuk yang melakukan tindakan pidana dianggap bertanggung jawab atas perbuatannya, karena sebelum mabuk seseorang sudah bisa berpikir akibat-akibat apa yang bisa terjadi pada seseorang yang sedang mabuk. ${ }^{20}$

Selanjutnya Undang-undang Nomor 36 Tahun 2009 tentang Kesehatan, diatur mengenai pengamanan zat adiktif pasal 44 yang berbunyi dengan Tujuan

a. Pengamanan penggunaan bahan yang mengandung zat adiktif diarahkan agar tidak mengganggu dan membahayakan kesehatan perorangan, keluarga, masyarakat, dan lingkungannya.

b. Produksi, peredaran, dan penggunaan bahan yang mengandung zat adiktif harus memenuhi standar dan atau persyaratan yang ditentukan.

c. Ketentuan mengenai pengamanan bahan yang mengandung zat adiktif sebagaimana dimaksud dalam ayat (1) dan ayat (2) ditetapkan dengan peraturan pemerintah.

Kemudian pengaturannya mengenai kandungan alkohol terdapat dalam peraturan menteri kesehatan tentang minuman keras nomor 86/Kes/Per/IV/77. Di dalam peraturan tersebut, minuman beralkohol digolongkan sebagai berikut:

Golongan A: Kadar etanol 1-5\%

Golongan B: Kadar etanol 5-20\%

Golongan C: Kadar etanol 20-55\%

Alkohol sebenarnya sangat dibutuhkan dalam dunia farmasi, banyak juga obat yang mengandung alkohol, meskipun kadarnya sangat rendah. Disamping untuk mensterilkan alat-alat kesehatan, alkohol kadang juga digunakan untuk menurunkan panas pada bayi yang sedang demam tinggi dengan jalan mengompres. ${ }^{21}$ Tujuannya dengan jalan mengompres dengan alkohol, panas cepat turun sehingga anak-anak terhindar dan stulp (kejang). Adapun tahapan bagi pecandu alkohol (alkoholisme). Dapat dikemukakan sebagai berikut: ${ }^{22}$

${ }^{20}$ Manan, B. (2000, July). Peningkatan Fungsi Kontrol Masyarakat Terhadap Lembaga Legislatif. In Eksekutif dan Yudikatif", Makalah pada Forum Orientasi dan Tatap Muka Tingkat Nasional Kosgoro, Cipanas-Cianjur (Vol. 26, pp. 1-2).

${ }^{21}$ Warassih, E., Medan, K. K., \& Mahmutarom. (2005). Pranata Hukum: Sebuah Telaah Sosiologis. Suryandaru Utama. hal, 29

22 Warassih, E., Medan, K. K., \& Mahmutarom. (2005). ibid, hal, 61 
a. Tahap pertama Dalam tahap ini dimulai serangan "black out", yakni seorang peminum tetap dalam keadaan sadar penuh. Keadaan ini berbeda dengan keadaan "passing out" atau pingsan. Dalam keadaan sadar ucapan serta perbuatannya nampak normal bagi orang-orang disekitarnya, tetapi ia sudah tidak ingat lagi dengan apa yang diucapkan selang beberapa saat.

b. Tahap kedua dalam tahap ini dicirikan dengan kehilangan pengendalian diri peminum alkohol tersebut tidak sanggup lagi berhenti minum, apabila ia sudah mulai minum. Disini ia sudah tidak bisa membatasi lagi untuk tidak minum dalam menjalani sisa hidup.

c. Tahap Ketiga Dalam tahap ini disebut dengan tingkat kronis yakni seorang peminum makin lama makin buruk kesehatannya, baik secara fisik, secara mental dan secara sosial. Seorang peminum akan mengalami demoralisasi, halusinasi (secara khayal ia bisa mendengar atau melihat sesuatu yang tidak ada), delirium (melihat yang seram-seram dalam khayalan) serta kehilangan kepercayaan din serta harapan untuk sembuh.

Berkaitan dengan masalah penggunaan alkohol, maka dampak yang terjadi jika seseorang mengkonsumsi minuman beralkohol secara berlebihan dalam waktu yang lama akan menimbulkan ketergantungan. Jika seseorang menderita alkoholisme tidak mendapat pasokan alkohol, akan mengakibatkan gejala putus alkohol. Gejala putus alkohol dapat dibagi menjadi 4 (empat) tingkat:

a. Tingkat Pertama Terjadi setelah 6-12 jam setelah minum alkohol terakhir. Gejala yang timbul berupa gelisah, denyut jantung meningkat, berkeringat, sukar tidur dan tekanan darah naik.

b. Tingkat kedua Terjadi setelah 24-36 jam setelah minum alkohol terakhir. Gejalanya disamping seperti pada tingkat pertama, disertai dengan halusinasi pendengaran dan penglihatan. Pada tingkat ini seharusnya diperlukan pengobatan.

c. Tingkat ketiga Pada tingkat ini bagi seorang alkoholik dapat terjadi kejangkejang akibat adanya pasokan alkohol pada tubuhnya.

d. Tingkat Keempat Pada tingkat keempat akibat tidak adanya pasokan alkohol akan terjadi delirium dan tremor, disorieniasi, bahkan terjadi halusinasi paranoid (rasa ketakutan dan curiga).

Gejala sindrom putus alkohol adalah sebagai berikut:

a. Gemetaran (tremor) kasar pada tangan, lidah dan kelopak mata.

b. Paling sedikit ada satu dan gejala berikut:

1) Mual dan muntah;

2) Kelemahan;

3) Hiperaktivitas syarat antonom, misalnya jantung berdebar-debar, berkeringat berlebihan dan tekanan darah meninggi.

4) Kecemasan (gelisah, tidak tenang, rasa ketakutan).

c. Perubahan akan perasaan menjadi pemurung dan mudah tersinggung. Banyak diantara peminum berat jatuh dalam keadaan depresi berat, timbulnya pikiran ingin bunuh din dan melakukan tindak bunuh diri.

d. Hipotensi ortostatik (tekanan darah menurun karena perubahan posisi tubuh: berbaring, duduk, dan berdiri).

e. Halusinasi dengar (mendengar suara-suara ancaman padahal tidak ada sumber atau stimulus suara itu) 
Adanya gejala sindrom putus alkohol tersebut, diatas yang dirasakan sebagai suatu penderitaan, maka orang lalu berupaya untuk minum-minuman alkohol dengan takaran yang semakin bertambah.23 Pengobatan ketergantungan alkohol, dapat berupa detoksifikasi dan rahabilitasi. Di Indonesia sudah terdapat kelompok pecandu alkohol yang berusaha untuk menghentikan kebiasaan tersebut. Kelompok tersebut menamakan dirinya Alcoholic Anonymous. Obat untuk membantu menghentikan kebiasaan minum alkohol antara lain Disulfiram. Obat tersebut telah digunakan sejak tahun 1940, dan bekerjanya menghambat pemecahan alkohol di dalam tubuh. Bekerja efektif setelah 1 jam, dan mempunyai efek samping seperti alergi kulit, rasa melayang, lekas lelah dan impotensi. Di dalam penggunaannya harus di bawah pengawasan Dokter. Meminum alkohol dalam jumlah banyak dalam waktu yang lama, akan menimbulkan berbagai akibat yang meliputi kesehatan fisik, kesehatan jiwa, gangguan fungsi sosial dan pekerjaan serta ketertiban dan keamanan.

a. Gangguan kesehatan fisik

Pada pemakaian minuman keras yang kronis dalam waktu yang lama akan mengakibatkan gangguan kesehatan fisik. Gangguan kesehatan terhadap fisik tersebut adalah:

1) Pengerasan hati (cirrhosis hepatitis). Dalam keadaan lanjut cirrhosis hepatitis (serosis hati) sering disertai dengan peningkatan tekanan vena porta (hipertensi portal). Penderita akan mengalami pengumpulan cairan di rongga perut, dan tidak jarang juga terjadi muntah darah dan buang air besar berwarna hitam.

2) Peradangan pada pankreas.

3) Peradangan lambung.

4) Disfungsi seksual (misalnya, impotensi pada pria).

5) Kekurangan gizi.

6) Pada wanita hamil, minuman keras akan mengakibatkan bayi yang dilahirkan mempunyai berat badan di bawah normal dan adanya keterbelakangan mental atau pertumbuhan janin yang tidak sempurna.

b. Gangguan kesehatan jiwa

Akibat minuman keras perasaan seseorang menjadi berubah. Seseorang menjadi mudah tersinggung, cepat marah, eksplosif dan destruktif Minuman keras akan menimbulkan kerusakan yang permanen pada jaringan otak. Sehingga menimbulkan:

1) Gangguan daya ingat.

2) Kehilangan kemampuan berkonsentrasi (misalnya, belajar).

3) Gangguan jiwa tertentu

Selanjutnya pada kasus keracunan alkohol dapat dibagi menjadi 5 (lima) tingkat, yaitu;

1) Tingkat sub klinik;

2) Tingkat Stimulasi;

3) Tingkat kebingungan;

4) Tingkat pingsan;

5) Tingkat koma.

\footnotetext{
${ }^{23}$ Warassih, E., Medan, K. K., \& Mahmutarom. (2005). ibid, hal, 51
} 
Wawancara Dari kasus kematian masyarakat akibat mengkonsumsi minuman beralkohol di Wiyalah Hukum Polres Wajo dari Tahun 2017-2019 yang tercatat pada data Satuan Resese Polres Wajo adalah 65 kasus. ${ }^{24}$ maka untuk lebih jelasnya akan ditampilkan dalam tabel berikut ini:

Tabel 1

Jumlah Kematian Masyarakat Akibat Mengkonsumsi Minuman Beralkohol Tahun 2017 - November 201925

\begin{tabular}{clll}
\hline No & Tahun & Jumlah Kasus & $\begin{array}{l}\text { Persentase } \\
\mathbf{( \% )}\end{array}$ \\
\hline 1 & 2017 & 3 kasus & $25 \%$ \\
\hline 2 & 2018 & 4 kasus & $33,33 \%$ \\
\hline 3 & 2019 & 5 kasus & $41,67 \%$ \\
\hline & Total & 12 Kasus & $100 \%$ \\
\hline
\end{tabular}

Terjadinya kematian masyarakat akibat mengkonsumsi minuman keras selang waktu tahun 2017 ke 2019 mengalami kenaikan dimana dari 25\% naik menjadi 41,67\%. Tujuan penulis dan hasil tersebut dapatlah memberikan suatu gambaran kepada kita bahwa matinya masyarakat Kabupaten Wajo yang disebabkan oleh mengkonsumsi minuman beralkohol masih banyak terjadi di lingkungan masyarakat Kabupaten Wajo.

Tabel 2

Jenis-Jenis Minuman Beralkohol yang beredar di Kabupaten Wajo Tahun 2017 s/d November 201926

\begin{tabular}{llllllll}
\hline No & $\begin{array}{c}\text { Jenis } \\
\text { Minuman }\end{array}$ & $\mathbf{2 0 1 7}$ & $\mathbf{9}$ & $\mathbf{2 0 1 8}$ & $\mathbf{\%}$ & $\mathbf{2 0 1 9}$ & $\mathbf{\%}$ \\
\hline 1 & Robinshon & 125 & 17,83 & 150 & 21,58 & 165 & 21,71 \\
\hline 2 & Milo & 305 & 43,50 & 250 & 35,97 & 245 & 32,23 \\
\hline 3 & Red Label & 50 & 7,13 & 60 & 8,63 & 70 & 9,21 \\
\hline 4 & Bir & 75 & 10,69 & 150 & 21,58 & 130 & 17,10 \\
\hline 5 & Vodka & 56 & 7,98 & 40 & 5,75 & 50 & 6,57 \\
\hline 6 & Jhon Wolker & 30 & 4,27 & 35 & 5,03 & 20 & 2,63 \\
\hline 7 & Jenever & 30 & 4,27 & 5 & 0,71 & 40 & 5,26 \\
\hline 8 & Wiro & 30 & 4,27 & 5 & 0,71 & 40 & 5,26 \\
\hline & Jumlah & $\mathbf{7 0 1}$ & $\mathbf{1 0 0 \%}$ & $\mathbf{6 9 5}$ & $\mathbf{1 0 0} \%$ & $\mathbf{7 6 0}$ & $\mathbf{1 0 0 \%}$ \\
\hline
\end{tabular}

Berdasarkan Tabel 2 menunjukkan bahwa dari Tahun 2017 s/d November 2019 minuman beralkohol yang paling banyak dan sering terjadi dikomsumsi masyarakat sehingga mengakibatkan hilangnya nyawa adalah Milo (Minuman Lokal). Pada kejadian tersebut Tahun 2017 sebanyak 3 kasus, Tahun 2019 sebanyak 4 kasus sedangkan Tahun 2018 sebanyak 5 kasus.

Bertolak dari uraian diatas dapat dikatakan bahwa matinya masyarakat Kabupaten Wajo pada umumnya sebagian besar akibat mengkonsumsi minuman beralkohol jenis minuman lokal, hal ini disebabkan karena minuman jenis minuman lokal tersebut tidak memiliki standar kandungan alkohol.

\footnotetext{
24 Risnah, Anggota Polri, Polres Wajo (Wawancara pada tanggal, 5 September 2019)

25 Data Reskrim Polres Wajo, 3 Tahun Terakhir (2017 - November 2019)

26 Data Reskrim Polres Wajo, 3 Tahun Terakhir (2017 - Maret 2019)
} 
Minuman lokal tersebut harganya harganya murah dan mudah dijangkau, bahkan minuman lokal tersebut 70\% dengan Coca-Cola atau Sprite, ketika dikonsumsi secara berlebihan secara otomatis akan membakar jantung dan merusak paru-paru mereka mengkonsumsi.

Faktor penyebab dikarenakan kurangnya kesadaran masyarakat terhadap kelangsungan hidup dirinya dan kesehatan pribadinya serta tidak maksimalnya DPRD Kabupaten Wajo melaksanakan Fungsi Pengawasan terhadap Peraturan Daerah dan Peraturan Bupati tentang Minuman Keras di Kabupaten Wajo. Kepolisian setempat kurang adanya deteksi dini sebagai antisipasi dalam pelaksanaan tugas serta kurangnya peran tokoh agama, tokoh masyarakat, tokoh pemuda, para intelektual dalam mengantisipasi peredaran minuman keras serta bahan-bahan medis yang dipergunakan tidak sesuai dengan peraturan kerja di Kabupaten Wajo, walaupun Kepolisian Resort Wajo dengan berbagai cara berusaha mendekati masyarakat lewat penyuluhanpenyuluhan hukum dan berbagai kegiatan lainnya, tetapi tidak mencapai hasil yang maksimal.

\section{Hambatan-Hambatan dalam Pelaksanaan Fungsi Pengawasan DPRD}

Tujuan dalam melaksanakan fungsi pengawasan DPRD terhadap Implementasi Peraturan Daerah dan Peraturan Bupati, tentu mengalami banyak hambatan-hambatan, yaitu yang dialami DPRD Wajo dalam melakukan pengawasan tidak terlepas daripada perubahan perundang-undangan yang ada seperti misalnya perubahan Undang-Undang tentang Pemerintahan Daerah hingga yang terbaru. ${ }^{27}$ Bertujuan dimana peranan DPRD dirasa sangat kuat sehubungan dengan DPRD yang memilih Kepala Daerah serta proses Pengangkatan Sekretariat Daerah juga terdapat peranan DPRD. Dari sisi pertanggungjawaban Kepala Daerah bahwa DPRD dapat menolak pertanggungjawaban Kepala Daerah dengan alasan-alasan yang dapat dipertanggungjawabkan.

Tujuanya Untuk mempertanggung jawabkan penolakan DPRD tersebut, maka dalam waktu 30 (tiga puluh) hari Kepala Daerah harus menyempurnakan pertanggungjawabannya dan disampaikan kembali ke DPRD. Jika terjadi penolakan yang kedua kalinya, maka DPRD dapat mengusulkan pemberhentian Kepala Daerah kepada Presiden. Namun dalam Undang-Undang Pemerintahan Daerah tidak terdapat lagi pertanggungjawaban Kepala Daerah terhadap DPRD, maka bagaimanapun perubahan tersebut akan mempengaruhi terhadap pengawasan DPRD terhadap Pemerintah Daerah khususnya terhadap Implementasi Peraturan Daerah dan Peraturan Bupati, dipengaruhi masalah kualitas anggota DPRD juga menjadi hambatan dalam pengawasan, ${ }^{28}$ seperti pernyataan pasang surut hubungan kewenangan antara DPRD dan Kepala Daerah, sebagai berikut: ${ }^{29}$

"Bahwa dari segi kualitas masih ada sebagian anggota DPRD yang belum memenuhi standar baik pendidikan maupun pengalaman yang diharapkan, hal

\footnotetext{
${ }^{27}$ Andi Alaiddin Palaguna, Ketua DPRD Kabupaten Wajo (Wawancara pada tanggal 8 November 2019)

${ }^{28}$ Andi Alaiddin Palaguna, Ketua DPRD Kabupaten Wajo (Wawancara pada tanggal 8 November 2019)

${ }^{29}$ Juanda, H. P. D. (2008). Pasang Surut Hubungan Kewenangan antara DPRD dan Kepala Daerah. Alumni, Bandung. hal, 26
} 
ini karena rekrutmen anggota Dewan yang tidak selektif, Akibatnya, sebagian dari anggota DPRD masih ada yang belum memahami secara benar tugas, wewenang, fungsi dan kewajibannya. Hal itu dapat dilihat dan dinilai pada waktu pandangan umum anggota DPRD dan pembahasan-pembahasan melalui panitia khusus dan panitia musyawarah".

Demikian halnya pengamatan yang dilaksanakan oleh penulis terhadap DPRD Wajo, bahwa sebagaimana yang disebutkan diatas juga ada benarnya, namun harus dipahami bahwa keberadaan DPRD sebagai pengawas adalah bahwa DPRD mewakili kumunitasnya, sehingga sudah pasti bahwa DPRD itu berasal dari berbagai latar belakang. ${ }^{30}$ Keanggotaan DPRD Wajo berasal dari latar belakang dan pengalaman yang berbeda, sehingga memiliki persoalan dan masalah tersendiri yang mempengaruhi kinerja, seperti misalnya faktor kehadiran para anggota DPRD dalam melaksanakan kegiatan.

Prilaku kehadiran Pimpinan/anggota DPRD yang tidak tepat waktu sehingga mengakibatkan molornya pelaksanaan kegiatan pengawasan. Pengawasan yang dilakukan oleh DPRD pada umumnya diakui sebagai instrumen politik oleh masing-masing partai politik yang disampaikan lewat fraksi. ${ }^{31}$ Sehingga pengawasan diarahkan pada kepentingan politik partai yang akibatnya akan mempengaruhi pengawasan itu kemana diarahkan. Kepala Daerah yang berasal dari fraksi yang ada di DPRD, maka pengawasan oleh fraksi tersebut pada dasarnya pengawasan itu hampir diabaikan, apalagi Kepala Daerah tersebut menguasai partai politik, sudah pasti Kepala Daerah akan mengendalikan kegiatan fraksi yang di DPRD. Menurut pengamatan penulis bahwa program kerja pengawasan lebih sering terabaikan hal ini dapat dilihat dari kegiatan pengawasan yang dilaksanakan di DPRD Wajo, maka program kerja pengawasan harus lebih konkrit.

Tingkat pendidikan dan "kondisi sosial ekonomi" juga mempengaruhi kinerja seorang anggota dewan, ${ }^{32}$ hasil penelitian di DPRD Kabupaten Wajo pengaruh sosial merupakan satu di antara sumber tingkah laku politik individu. Selanjutnya, mereka status sosial yang tinggi seperti pengusaha dan professional umumnya lebih terlibat dalam hal pemikiran-pemikiran politik, sedangkan yang cenderung bersikap apolitis biasanya adalah mereka yang berasal dari kelompok sosial ekonomi lebih rendah." 33 Karena DPRD adalah berasal dari partai politik, maka kendala dalam pelaksanaan tugas DPRD termasuk fungsi pengawasan adalah sehubungan dewan selalu sibuk dalam mengurusi urusan partai politik, walaupun diatur dalam tata tertib bahwa tugas dewan harus diutamakan daripada urusan lain, namun pada kenyataannya dewan selalu mengutamakan urusan politik. ${ }^{34} \mathrm{Hal}$ ini tentu karena dewan

\footnotetext{
30 Sembiring, S. (2009). Himpunan Peraturan Perundang-Undangan Republik Indonesia. Pemerintahan Daerah (Pemda), Bandung, Nuansa Aulia. Hal, 59

31 Sembiring, S. (2009.ibid. Hal, 61

32 Soeparmo, (2006) Pengawasan Administrasi Dan Pengawasan Pelaksanaan APBD, Bahan Presentase Pada Kegiatan Pembekalan DPRD Kab. Serdang Bedagai, Dari Badan Pemeriksa Keuangan Perwakilan Medan. Hal, 71

${ }^{33}$ Ridwan, A. (2015). Fungsi Pengawasan Dewan Perwakilan Rakyat Daerah (DPRD) terhadap Kinerja Pemerintahan Daerah dalam Mewujudkan Aparatur Pemerintahan yang Bersih Bebas dari Korupsi Kolusi Nepotisme (KKN)(Studi di Kabupaten Bombana) (Doctoral dissertation, Fakultas Hukum Unissula). hal, 46

${ }^{34}$ Hasmin, M. Y. (2017). Kualitas Keterwakilan Rakyat Melalui Dewan Perwakilan Rakyat Menurut Sistem Politik Di Indonesia. Al-Ishlah: Jurnal Ilmiah Hukum, 19(2), 1-11.
} 
berasal dari partai politik, apalagi sesuai dengan Undang-undang Nomor 13 Tahun 2019 tentang Majelis Permusyawaratan Rakyat, Dewan Perwakilan Rakyat, Dewan Perwakilan Daerah, dan Dewan Perwakilan Rakyat Daerah, bahwa partai politik dapat mencekal anggotanya yang ada di dewan.

Beragam hambatan-hambatan dalam melaksanakan Pengawasan Terhadap Implementasi Perda dan Peraturan Bupati dapat dikategorikan hambatan yang berasal dari dewan itu sendiri atau faktor internal, maupun hambatan dari luar dewan atau faktor eksternal, adapun diantaranya: ${ }^{35}$

a. Hambatan Faktor Internal

(1) Pendidikan. Kualitas pendidikan anggota dewan, dimana latar belakang pendidikan dewan baik pendidikan formal, informal maupun non formal yang dimiliki sangat mempengaruhi pengawasan.

(2) Karena semakin tinggi tingkat pendidikan maka semakin tinggi juga tingkat partisipasi politiknya. Pendidikan yang hanya sekedar memenuhi persyaratan dasar calon dewan, akan mempengaruhi kualitas pekerjaan, bahkan hingga dewan tidak mengerti apa yang harus dilakukan.

(3) Pengalaman Keanggotaan DPRD Wajo, dimana hanya 4 (empat) dari 40 (empat puluh ) anggota dewan yang memiliki pengalaman sebagai dewan sebelumnya, maka dengan sedikinya dewan yang punya pengalaman tersebut akan mempengaruhi kegiatan dalam pengawasan. Pengalaman adalah sangat berharga, jika pendidikan ditambah dengan pengalaman maka akan dapat memaksimalkan pengawasan.

(4) Kondisi sosial ekonomi Kondisi sosial ekonomi anggota DPRD Kabupaten Wajo tersebut hanya sedikit yang berprofesi sebagai pengusaha maupun orang profesional, bahkan didominasi dari kelompok sosial biasa maupun rendah. Sehingga sebagaimana pendapat yang diuraikan di atas, bahwa kondisi seperti inilah yang menghambat pengawasan DPRD Kabupaten Wjo, karena pengawasan tersebut sifatnya akan mengarah pada apolitis atau mengarah pada pragmatis.

(5) Program kerja yang jelas dan terukur sangat dibutuhkan dalam melaksanakan tugas pengawasan, maka hambatan dalam pengawasan sebagaimana hasil pengamatan dan wawancara peneliti adalah akibat dari program kerja bidang pengawasan kurang jelas operasionalnya. Karena pengawasan yang dilakukan adalah jika ada kasus atau temuan maka pengawasan itu dilaksanakan.

(6) Sekretariat. DPRD Kabupaten Wajo adalah yang memfasilitasi kegiatan DPRD, maka akibat sekretariat yang tergolong baru dalam melaksanakan tugas sebagai sekretariat dewan, karena kabupaten yang baru maka pelaksanaan pengawasan akan mempengaruhi. Jika pengalaman dewan masih kurang namun jika didukung dengan sekretariat yang berpengalaman, maka tugas pengawasan dapat maksimal. Berdasarkan pengamatan peneliti bahwa tugas sekretariatan masih belum maksimal, bukan karena ketidak terbukaan dewan akan tetapi karena masih kurangnya pengalaman dalam menjalankan tugas sekretariatan, khususnya tugas pada Sekretariatan DPRD Kabupaten Wajo.

35 Sembiring, S. (2009.ibid. Hal, 61 


\section{b. Hambatan Faktor Eksternal}

(1) Perubahan peraturan perundang-undangan Perubahan dalam peraturan perundang-undangan yang berlaku dalam pelaksanaan sistim pemilihan akan manjadi masalah tersendiri dalam pengawasan. Memang perubahan undang-undang pemilihan adalah dengan maksud lebih demokratis, namun dalam upaya memahami perundang-undangan yang baru akan butuh waktu dalam sosialisasi apalagi dalam penerapannya, peran DPRD sangat strategis dan menentukan, karena kepala daerah harus menyampaikan Laporan Pertanggungjawaban (LPJ) setiap tahunnya kepada DPRD, bahkan jika dua kali ditolak LPJ kepala daerah dapat berujung pada pengusulan pemecatan kepala daerah kepada Presiden. LPJ Kepala Daerah telah dirubah menjadi Laporan Keterangan Pertanggunjawaban (LKPJ), yang prinsifnya DPRD hanya mengesahkan LKPJ Kepala Daerah setelah diaudit oleh Badan Pemeriksa Keuangan (BPK). Sehingga DPRD tidak ada istilah penolakan terhadap LKPJ Kepala Daerah, maka hal ini akan berdampak pada Pengawasan DPRD. Karena Kepala Daerah/Bupati tidak bertanggungjawab lagi terhadap DPRD.

(2) Rekrutmen partai politik Dalam rekrutmen calon anggota dewan, sebagimana yang diatur dalam sistim pemilihan umum, bahwa rekrutmen itu ditentukan oleh masing-masing partai politik sepanjang sesuai dengan undang-undang. Karena rekrutmen partai politik tidak selektif dalam mengusung calon dewan, maka yang terjadi bahwa kualitas DPRD masih sangat jauh dari harapan. Kondisi seperti ini merupakan persoalan bangsa yang tidak pernah selesai, jika pengaturan tentang rekrutmen tidak diatur sedemikian rupa.

(3) Partisipasi masyarakat dan media Partisipasi masyarakat Kabupaten Wajo dan media sangat dibutuhkan DPRD dalam melakukan pengawasan, karena jika masyarakat memberikan partisipasi atas pengawasan kinerja pemerintah daerah serta didukung dengan publikas lewat media maka, dewan akan lebih giat dalam melaksanakan tugas pengawasannya. Sebab sasaran dari pada Peraturan Daerah dan Peraturan Bupati itu dibuat adalah untuk kepentingan masyarakat, maka sewajarnya ada partisipasi masyarakat dalam memberikan informasi kepada DPRD.

\section{SIMPULAN DAN SARAN}

Pengaturan fungsi Pengawasan DPRD terhadap Pemerintah Daerah adalah pengawasan bagian dari pada fungsi DPRD. Fungsi pengawasan DPRD terhadap Pemerintah Daerah dapat dilaksanakan melalui kedudukan dan fungsi, tugas dan wewenang serta hak dan kewajiban DPRD. Jika kedudukan, fungsi, tugas wewenang serta hak DPRD dapat dijalankan, maka peranan DPRD sebenarnya sudah maksimal dalam menjalankan peranannya sebagai lembaga perwakilan rakyat daerah. Hambatan-hambatan dalam melaksanakan Pengawasan DPRD Wajo adalah ada yang berasal dari internal dewan dan dari luar dewan. Hambatan dari dalam misalnya masalah pendidikan, dimana pendidikan yang dimiliki DPRD Wajo dapat menghambat pengawasan karena kurangnya kemampuan yang dimiliki, serta pendidikan yang tidak ada relevansinya dengan tugas dewan. Kurangnya pengalaman yang dimiliki DPRD merupakan hambatan dalam melakukan pengawasan. Karena anggota DPRD Wajo sangat sedikit yang memiliki pengalaman, seingga sangat mempengaruhi pengawasan. Masalah kondisi sosial ekonomi anggota dewan juga mempengaruhi pengawasan, karena kondisi sosial ekonomi yang rendah akan mengakibatkan 
pengawasan yang bersifat apolitis dan pragmatis. Program kerja yang tidak jelas dan tidak terarah dalam membuat program kerja bidang pengawasan juga menjadi hambatan dalam pengawasan. Demikian halnya dengan sekretariatan yang masih baru serta belum punya pengalaman dalam menjalankan tugas sebagai sekretariat dewan, maka menjadi hambatan dalam memaksimalkan pengawasan. Hambatan yang berasal dari luar dewan dalam rangka pengawasan adalah mengenai perubahan perundang-undangan tentang pemerintahan daerah. Dengan terjadinya perubahan perundang-undangan akan menghambat dalam pelaksanaan pengawasan, karena dalam penyesuaian undang-undang tersebut membutuhkan waktu dalam pelaksanaannya. Demikian halnya dengan kualitas Sumber Daya Manusia anggota DPRD Wajo, sangat mempengaruhi pengawasan. Karena sumber daya manusia yang rendah akan menghambat pengawasan, namun persoalan ini adalah masalah rekrutmen yang dilakukan partai politik. Partisipasi masyarakat dan media yang kurang terhadap pelaksanaan kinerja pemerintah daerah, juga menghambat pengawasan. Sebab jika partisipasi masyarakat dan media masa maksimal, maka pengawasan DPRD Wajo akan maksimal, sebab tidak semua kegiatan pemerintah daerah dapat diawasi DPRD.

Artikel ini menyarankan bahwa pendidikan formal sebagai anggota DPRD Wajo seharusnya diberikan batasan yakni minimal berpendidikan Diploma 3 (tiga), sebab bagaimana mungkin sebagai anggota DPRD Wajo yang hanya berpendidikan setara Sekolah Menengah Atas serta tidak memiliki pengalaman yang cukup dapat mengawasi pemerintah daerah yang sangat komplek. Perlu dilaksanakan model pendidikan alternatif melalui pengembangan pola inservice training (pelatihan dalam pelayanan) seperti pendidikan kondisional yang profesional guna mewujudkan kapasitas intelektual para anggota DPRD di satu sisi, dan disisi lain mendorong peningkatan kualitas kelembagaan dewan dalam mengemban fungsi konstitusionalnya. Alasan dalam pelaksanaan penegakan Perda khususnya Perda Minuman Keras di Kabupaten Wajo tidak serta merta dilakukan penindakan oleh Kepolisian setempat sebagai mitra pemerintah selagi tidak terjadi suatu tindak pidana, dikarenakan didalam proses penegakan Perda bukan ranah Kepolisian melainkan ranah Penyidik Pegawai Negeri Sipil, dan di Kabupaten Wajo belum dibentuknya Penyidik Pegawai Negeri Sipil, diharapkan Pemerintah Kabupaten Wajo dapat menyiapkan Penyidik Pegawai Negeri Sipil di lingkungan Pemerintah Kabupaten Wajo, sehingga penegakan Perda dapat berjalan dengan maksimal.

\section{DAFTAR RUJUKAN}

Bubandt, N. (2014). Menuju Sebuah Politik Tradisi Yang Baru? Desentralisasi, Konflik, dan Adat di Wilayah Indonesia Timur. Antropologi Indonesia.

Djojosoekarto, A. (2004). Dinamika dan kapasitas DPRD dalam tata pemerintahan demokratis. Konrad Adenauer Stiftung.

Mahfud, M. (1999). Pergulatan politik dan hukum di Indonesia. Gama Media.

Juanda, H. P. D. (2008). Pasang Surut Hubungan Kewenangan antara DPRD dan Kepala Daerah. Alumni, Bandung.

Hasmin, M. Y. (2017). Kualitas Keterwakilan Rakyat Melalui Dewan Perwakilan Rakyat Menurut Sistem Politik Di Indonesia. Al-Ishlah: Jurnal Ilmiah 
Hukum, 19(2), 1-11.

Manan, B. (2000, July). Peningkatan Fungsi Kontrol Masyarakat Terhadap Lembaga Legislatif. In Eksekutif dan Yudikatif", Makalah pada Forum Orientasi dan Tatap Muka Tingkat Nasional Kosgoro, Cipanas-Cianjur (Vol. 26, pp. 1-2).

Muchsan, M. (1992). Sistem Pengawasan terhadap Perbuatan Aparat Pemerintah dan Peradilan Tata Usaha Negara di Indonesia. Yogyakarta: Liberty.

Napitupulu, P. (2007). Menuju pemerintahan perwakilan. Alumni.

Nawi, S. (2014). Penelitian Hukum Normatif Versus Penelitian Hukum Empiris. Umitoha Ukhuwah Grafika, Makassar.

Ndraha, T. (2005). Kybernologi: sebuah rekonstruksi ilmu pemerintahan. Rineka Cipta.

Nurdin, A. (2020). Implementasi Fungsi Legislasi Dewan Perwakilan Rakyat Daerah pada Pembentukan Peraturan Daerah. Al-Ishlah: Jurnal Ilmiah Hukum, 22(1), 53-76.

Ridwan, A. (2015). Fungsi Pengawasan Dewan Perwakilan Rakyat Daerah (DPRD) terhadap Kinerja Pemerintahan Daerah dalam Mewujudkan Aparatur Pemerintahan yang Bersih Bebas dari Korupsi Kolusi Nepotisme (KKN)(Studi di Kabupaten Bombana) (Doctoral dissertation, Fakultas Hukum Unissula).

Sampara, S. La Ode Husen. (2016). Metode Penelitian Hukum Edisi Revisi. Kretakupa, Makassar.

Sembiring, S. (2009). Himpunan Peraturan Perundang-Undangan Republik Indonesia. Pemerintahan Daerah (Pemda), Bandung, Nuansa Aulia.

Soeparmo, (2006) Pengawasan Administrasi Dan Pengawasan Pelaksanaan APBD, Bahan Presentase Pada Kegiatan Pembekalan DPRD Kab. Serdang Bedagai, Dari Badan Pemeriksa Keuangan Perwakilan Medan.

Syuhudi, I. (2018). Pergulatan Kepentingan Politik Dalam Relasi Inter Denominasi Kristen Di Manado. Al-Qalam, 24(2), 235-245.

Warassih, E., Medan, K. K., \& Mahmutarom. (2005). Pranata Hukum: Sebuah Telaah Sosiologis. Suryandaru Utama.

Wasistiono, S., \& Riyani, O. (2003). Etika Hubungan Legislatif-Eksekutif dalam Pelaksanaan Otonomi Daerah. Fokusmedia. Cet. ke-2. Bandung.

Undang-Undang Nomor 4 Tahun 1957 tentang Pembubaran Daerah Bone dan Pembentukan Daerah Bone, Daerah Wajo dan Daerah Soppeng

Peraturan Pemerintah Nomor 12 tahun 2017 tentang Pembinaan dan Pengawasan Penyelenggaraan Pemerintahan Daerah. (Lembaran Negara republik Indonesia Tahun 2017 Nomor 73, Tambahan Lembaran Negara Republik Indonesia Nomor 6041) 
Pleno Jure, Vol 9 (2), Mustari Mustari, Pengawasan DPRD Terhadap Implementasi...

Peraturan Pemerintah Nomor 41 Tahun 2007 tentang Organisasi Perangkat Daerah (Lembaran Negara Republik Indonesia Tahun 2007 Nomor 89, Tambahan Lembaran Negara Republik Indonesia Nomor 4741). 